\title{
TINJAUAN HUKUM PERAN PERS GUNA MENEGAKKAN HAK ASASI MANUSIA DI INDONESIA
}

Oleh :

M. Syahnan Harahap, SH, M.Hum.

\begin{abstract}
Abstrak:
Pers sebagai lembaga sosial dan wahana komunikasi massa memegang peranan sangat penting dalam membentuk opini publik dan pemahaman masyarakat atas suatu kebijakan dan masalah-masalah yang dihadapi bangsa dan negara. Apakah opini publik itu akan bersifat positif atau sebaliknya negatif sedikit banyak dipengaruhi oleh pemberitaan, tulisan, ulasan dan analisis yang dikembangkan media massa
\end{abstract}

\section{PEMBAHASAN}

Memang harus diakui peranan pers dalam mengawasi dan menegakkan nilai- nilai hak asasi manusia (HAM) sebelum dan sesudah amandemen UUD-45, sangat berbeda. Pada era sebelum amandemen UUD-45, tepatnya di era Orde Baru, pers praktis tidak bebas. Karena ada sejumlah ketentuan yang membatasi kebebasan pers sekalipun pasal 28 UUD-45 menjamin hal itu. Antara lain Peraturan Menteri Penerangan (Permenpen) No. 1 tahun 1984 tentang Surat ijin Usaha Penerbitan Pers (SIUP) berdasarkan UU No. 21 tahun 1982 tentang ketentuan- ketentuan pokok pers, sangat membatasi kebebasan pers. Tidak lain karena dalam salah satu pasal Permenpen itu dimungkinkan pembatalan SIUP apabila media dinilai tidak lagi mencerminkan sebagai pers Pancasila. Tidak heran kalau pers di zaman itu dihantui oleh pembatalan SIUP.

Pada sisi lain, UU-45 sebelum amandemen boleh dibilang sangat sumir mengatur soal- soal HAM. Pengaturan soal HAM yang sangat sumir itu pun disepakati oleh para perumus UUD-45 melalui perdebatan yang sangat a lot pada sidang- sidang Badan Penyelidik Usaha Persiapan Kemerdekaan Indonesia (BPUPKI) tahun 1945. Pengaturan soalsoal HAM yang sangat sumir dalam konstitusi seperti ini, jelas sangat tidak membantu pers dalam mengawasi dan menegakkan nilai- nilai kemanusiaan.

Akan tetapi setelah amandemen UUD-45, peranan pers dalam mengawasi dan menegakkan HAM dijamin sepenuhnya. 
Sebagai contoh, dalam pasal 28 F UUD-45 ditegaskan bahwa, setiap orang berhak untuk berkomunikasi dan memperoleh informasi untuk mengembangkan pribadi dan lingkungan sosialnya, serta berhak untuk mencari, memperoleh, memiliki, menyimpan, mengolah dan menyampaikan informasi dengan menggunakan segala jenis saluran yang tersedia.

Bahkan kalau mau dikaji lebih lanjut, ketentuan pasal 28 F UUD-45 tersebut telah mengakomodir perjuangan gigih pers nasional selama ini. Perlu dicatat bahwa kebebasan pers yang diperjuangkan sejak Orde Baru adalah kebebasan pers bersifat terbatas. Hal ini perlu dikemukakan karena perjuangan pers di era Orde Baru dan Orde Lama pada hakikatnya masih dalam arti sempit, yaitu terbatas pada prinsip "freedom from" (bebas dari). Bebas dari apa ? Bebas dari tekanan, bebas dari terror, bebas dari sensor, bredel, bebas dari "budaya telepon", bebas dari pembatalan SIUP dan lainnya.

Padahal perjuangan kebebasan pers yang sebenarnya tidak terbatas pada "freedom from" saja, melainkan jauh lebih mendasar dan lebih luas dari itu, yakni "freedom for" (bebas untuk). Konkretnya, bebas untuk mencari, memperoleh, mengumpulkan, menyimpan, mengolah dan menyebarluaskan gagasan dan informasi. Itulah sebabnya dikatakan pasal 28 F UUD-45 telah mencakup perjuangan pers selama ini dalam arti luas, "freedom for".

Makna kemerdekaan pers yang demikian itu, juga sudah diatur secara tepat dalam UU.No. 40 tahun 1999 tentang Pers (UU.Pers). dalam pasaal 4 UU.Pers, dijamin empat hal penting dan mendasar seperti :
1. Kemerdekaan pers dijamin sebagai hak asasi warga negara;

2. Terhadap pers nasional tidak dikenakan sensor, pembredelan atau pelarangan penyiaran;

3. Untuk menjamin kemerdekaan pers, pers nasional mempunyai hak mencari, meperoleh, dan menyebar luaskan gagasan dan informasi;

4. Wartawan mempunyai hak tolak.

Jelas bahwa peranan pers dalam mengawasi dan mengakkan HAM sebelum dan sesudah amandemen UUD45 sangat berbeda.

Namun harus diakui bahwa sekalipun peranan pers dalam mengawasi dan menegakkan HAM sudah dijamin sepenuhnya oleh konstitusi dan peraturan perundang- undangan dibidang pers pasca amandemen UUD_45, akan tetapi tidak dengan sendirinya kemerdekaan pers tersebut bebas dari gangguan atau distorsi. Berdasarkan pengalaman paling tidak ada empat tindakan atau perbuatan yang bisa mendistorsi kemerdekaan pers.

Keempat tindakan atau perbuatan dimaksud, (1) berupa distorsi melalui peraturan perundang- undangan seperti halnya Permen tentang SIUP dan sejumlah undang- undang yang masih berlaku, berpotensi menggangu kemerdekaan pers. Termasuk adanya sekitar 37 pasal dalam KUHPidana yang dapat menyeret wartawan masuk penjara. Kemudian (2), melalui birokrasi seperti "budaya telepon" : di Era Reformasi, budaya telepon praktis tidak ada lagi. Namun berdasarkan pengalaman masih terlalu sering aparat keamanan bertindak berlebihan dengan mengusir, memukul, menganiaya dan lain- lain. Semua tindakan itu berpotensi mendistorsi kemerdekaan pers. Tapi gangguan itu 
bisa juga datang dari (3) masyarakat melalui tindakan "main hakim sendiri".

Seringkali media diteror, diancam, kantornya diduduki dan dirusak oleh massa apabila ada berita atau tulisan yang dinilai merugikan atau tidak sesuai dengan kenyataan yang sebenarnya. Padahal tidakan "main hakim sendiri" itu tidak perlu dilakukan karena ada mekanisme yang bisa ditempuh berupa hak jawab dan hak koreksi sesuai ketentuan UU.Pers. hak jawab dan hak koreksi itu menurut UU.Pers merupakan wujud kontrol masyarakat terhadap pers.

Dalam praktek gangguan tersebut bisa juga datang (4) dari kalangan pers itu sendiri. Antara lain berupa penyajian berita yang tidak mentaati norma etik dan norma hukum. Akibatnya pers atau wartawan terpaksa dihadapkan kemeja hijau apakah itu karena gugatan perdata atau tuntutan pidana. Yang menarik adalah gugatan perdata menyangkut tuntutan ganti rugi yang jumlahnya sangat fantastic meliputi miliaran rupiah atau triliunan rupiah. Bisa dibayangkan bagaimana jadinya bila tuntutan ganti rugi miliaran dan triliunan rupiah itu dikabulkan hakim. Bukan tidak mungkin perusahaan pers tersebut gulung tikar karena harus membayar ganti rugi yang demikian besar. Jadi disini distorsi itu datang dari diri insane pers itu sendiri. Itu berarti, media ditutup bukan karena tindakan yang datang dari luar, tapi datang dari dalam melalui penyajian berita dan tulisan yang tidak sesuai dengan norma etik dan norma hukum. Kenyataan inilah yang disebut distorsi atas kemerdekaan pers yang datang dari insane pers itu sendiri.

Dari uraian diatas jelas bahwa sekalipun konstitusi dan UU.Pers sudah sangat menjamin kemerdekaan pers, tapi masih sangat dimungkinkan terjadinya gangguan atas kemerdekaan pers tersebut. Oleh karena itu untuk menghindari gangguan dimaksud, maka selain menyempurnakan / merevisi sejumlah perundang- undangan yang berpotensi mendistorsi kemerdekaan pers, masyarakat juga perlu menyadari bahwa kemerdekaan pers merupakan perwujudan dari kedaulatan rakyat, sehingga mereka ikut bertanggung jawab menjaga dan memelihara kemerdekaan pers dimaksud. Kewajiban konstitusi ini kiranya perlu disosialisasikan sedemikian rupa sehingga disatu sisi fungsi, hak dan kewajiban serta peranan pers terselenggara dengan baik dan disisi lain masyarakat terhindar dari cara- cara pemberitaan yang oleh masyarakat disebut "Junalisme anarki", "Jurnalisme Profokasi", "Jurnalisme Preman", "Jurnalisme Pelintir", "Jurnalisme Hitam", dan lainnya sebitan yang merusak citra pers nasional.

Memang kalau kita lebih teliti dan lebih dalam lagi mengkaji fungsi, hak dan peranan pers menurut UUPers, kama pers punya peluang yang sangat menjanjikan dalam mengawasi dan mengakkan HAM dinegeri ini. Dalam penjelasan umum Pers secara eksplisit ditegaskan bahwa, pers yang memiliki kemerdekaan untuk mencari dan menyampaikan informasi juga sangat penting untuk mewujudkan HAM yang dijamin dengan Ketetapan MPR No. XVII / MPR / 1998 tentang HAM, antara lain yang menyatakan bahwa setiap orang berhak berkomunikasi dan memperoleh informasi sejalandengan Piagam PBB tentang HAM pasal 19 yang berbunyi : "Setiap orang berhak atas kebebasan mempunyai dan mengeluarkan pendapat; dalam hal ini termasuk kebebasan memiliki pendapat tanpa gangguan, dan untuk mencari, menerima, dan menyampaikan informasi dan buah pikiran melalui media apa saja dan 
dengan tidak memandang batas- batas wilayah".

Mengenai fungsi pers, pasal 3 ayat (1) UUPers, menegaskan pers nasional menpunyai fungsi sebagai media informasi, pendidikan, hiburan dan kontrol sosial. Kemudian mengenai hak pers, pasal 4 UUPers menetapkan bahwa kemerdekaan pers dijamin sebagai hak asasi warga negara. Terhadap pers nasional tidak dikenakan penyensoran, pembredelan, atau pelarangan penyaran. Untuk menjamin kemerdekaan pers, pers nasional mempunyai hak mencari, memperoleh dan menyebarluaskan gagasan dan informasi. Sedangkan dalam mempertanggung jawabkan pemberitaan di depan hukum, wartawan mempunyai hak tolak.

Penjelasan pasal 4 UUPers itu menyatakan, yang dimaksud dengan "kemerdekaan pers dijamin sebagai hak asasi warga negara" adalah bahwa pers bebas dari tindakan pencegahan, pelarangan, dan atau penekanan agar hak masyrakat untuk memperoleh informasi terjamin. Bagaimana dengan peranan pers Nasional ?. Dalam pasal 6 UUPers ditetapkan secara rinci peranan pers nasional yaitu :

1. Memenuhi hak masyarakat untuk mengetahui;

2. Menegakkan nilai- nilai dasar demokrasi, mendorong terwujudnya supremasi hukum dan HAM serta menhormati Kebhinekaan;

3. Mengembangkan pendapat umum berdasarkan informasi yang tepat, akurat dan benar;

4. Melakukan pengawasan, kritik, koreksi, dan saran terhadap hal- hal yang berkaitan dengan kepentingan umum;
5. Memperjuangkan keadilan dan kebenaran.

Dengan pengaturan yang jelas dan rinci oleh peraturan perundang- undangan tentang fungsi, hak dan peranan pers nasional seperti itu, maka tidak terlalu berlebihan apabila pers diharapkan dapat secara efektif mengawasi dan menegakkan HAM. Namun dalam kenyataannya jaminan UUPers tersebut tidak dengan sendirinya terselenggara dengan baik sebagaimana mestinya. Sebab selain jumlah kendala yang dihadapi pers seperti dikemukakan dibagian terdahulu, implementasi ketentuan UUPers tentang fungsi, hak dan peranan pers tersebut juga menghadapi berbagai hambatan bersumber dari pengaturan serta perumusan pasal- pasal yang mengandung sejumlah kelemahan. Ambil contoh mengenai fungsi pers sebagai media informasi, pendidikan, hiburan dan kontrol sosial. Rumusan fungsi pers tersebut memang ideal sekali. Tapi apa bentuk sanksi yang bisa dikenakan apabila fungsi pers ini mengalami hambatan atau gangguan, sebab UUPers tidak mengatur mengenai hal itu.

Demikian juga mengenai fungsi kontrol sosial, seringkali dalam praktek dilapangan kontrol sosial yang dilakukan pers itu justru dikualifikasi sebagai penghinaan atau pencemaran nama baik. Yang memprihatinkan lagi ialah, kontrol pers yang dilakukan untuk kepentingan umum direspons dengan mengancamkan pasal- pasal pidana dalam KUHP yang sudah usang. Apabila tidak bisa dipungkiri pasal- pasal yang ada kaitan dengan pers dalam KUHP menganut paradigma kriminalisasi atas karya jurnalistik. Ada sekitar 37 pasal dalam KUHPidana yang bisa menyeret wartawan masuk penjara. Lebih- lebih lagi dalam KUHPidana warisan pemerintah 
kolonial Belanda ini terdapat pasal- pasal yang terkenal dengan haatzaai artikelen. Pasal- pasal inilah yang dikenakan terhadap para wartawan. Padahal perumusan pasal- pasal tersebut sangat umum, sehingga bersifat karet. Dengan rumusan bersifat karet seperti itu memberi peluang bagi penguasa untuk menafsirkan dan mengancamkannya kepada siapa saja yang ingin dijadikan korban, termasuk terhadap wartawan.

Oleh karena itulah Haatzaai Artikelen tersebut oleh pers disebut sebagai "ranjau- ranjau pers". Tidak lain karena penerapan pasal- pasal itu terhadap kemungkinan kekeliruan dan kesalahan dalam pembuatan berita oleh wartawan sangat mematikan. Apalagi karena sifat deliknya adalah delik formal sehingga tidak ada kewajiban penyidik untuk membuktikan terlebih dahulu apakah sebagai akibat suatu tulisan telah ditimbulkan perasaan kebencian dan permusuhan dalam masyarakat terhadap pemerintah yang sah. Artinya, dengan diterbitkannya sebuah tulisan atau berita, dan apabila isinya dinilai bersifat menyebarluaskan perasaan kebencian dan permusuhan dalam masyarakat, telah cukup alasan bagi penyidik untuk menyeret wartawan bersangkutan ke pengadilan. Padahal sewaktu haatzaai artikelen itu diberlakukan di India waktu dijajah Inggris (British Indian Penal Code), sifat deliknya adalah delik materiil. Dengan delik materiil, ada kewajiban penyidik untuk membuktikan terlebih dahulu apakah sebagai akibat diterbitkannya sebuah berita atau tulisan telah timbul perasaan kebencian dan permusuhan dalam masyrakat terhadap pemerintah yang sah.

Jelas bahwa keberadaan "ranjau- ranjau pers" ini dalam KUHPidana yang masih berlaku sampai sekarang tidak menciptakan iklim kondusif bagi pers untuk memperjuangkan serta menegakkan keadilan dan kebenaran termasuk HAM dinegeri ini. Lagi pula, kalau memang terjadi kekeliruan atau kesalahan dalam karya Jurnalistik, maka seharusnya diselesaikan melalui UU No. 40 tahun 1999 tentang Pers, tidak langsung diproses secara hukum. Kecuali apabila terbukti ada niat jahat dalam pembuatan satu berita atau peliputan investigasi, tidak ada keberatan kalau diproses secara hukum.

Akan tetapi yang menarik untuk dibahas lebih lanjut ialah, berbagai tindak kekerasan yang dilakukan terhadap wartawan yang menjalankan tugas dan kegiatan jurnalistik. Tindak kekerasan seperti itu jelas tidak mendukung peranan pers menegakkan HAM. Berbicara mengenai tindak kekerasan tidak hanya secara fisik, tapi juga secara non fisik. Terutama yang dimaksud secara non fisik adalah, pelaksanaan ketentuan perundangundangan secara kaku atau tidak dilaksanakannya ketentuan hukum positif secara konsekuen dan konsisten.

Sebagai ilustrasi disebut disini pelaksanaan pasal- pasal pidana dalam KUHPidana yang berkaitan dengan pekerjaan pers secara kaku, dapat dikategorikan sebagai tindak kekerasan. Dikatakan demikian karena dengan diterapkannya pasal- pasal tergolong usang dalam KUHPidana berkenaan dengan pekerjaan pers, dapat diartikan atau diinterpretasikan sebagai mengganggu atau menghambat pelaksanaan tugas - tugas jurnalistik.

Sekedar contoh, pasal 4 ayat (3) UU No. 40 tahun 1999 tentang Pers telah menegaskan bahwa, untuk menjamin kemerdekaan pers, pers nasional mempunyai hak mencari, memperoleh, dan menyebarluaskan gagasan dan 
informasi. Dan apabila ketentuan ini dilanggar, dikenakan sanksi cukup berat. Kemudian pasal 18 ayat (1) UUPers ditegaskan, setiap orang yang secara melawan hukum dengan sengaja melakukan tindkan yang berakibat menghambat atau menghalangi pelaksanaan ketentuan pasal 4 ayat (2) dan ayat (3) dipidana dengan pidana penjara paling lama 2 (dua) tahun atau denda paling banyak Rp. 500.000 .000 (lima ratus juta rupiah).

Pada sisi lain, pers nasional punya catatan panjang tentang tindak kekerasan yang dilakukan terhadap wartawan, baik itu oleh aparat keamanan maupun oleh kelompok masyarakat. Tindak kekerasan terhadap wartawan itu berupa pengusiran, pemukulan, penganiayaan, perampasan peralatan, perusakan kantor, pendudukan ruang kerja redaksi, terror, dan lain- lain tindakan yang berakibat terganggu dan terhambatnya wartawan menjalankan tugas- tugas jurnalistiknya.

Sebenarnya, kalau kita mengacu pada ketentuan pasal 4 ayat (3) UUPers, tindakan yang berakibat menghambat atau menghalangi tugas - tugas kewartawanan dapat diancam pidana, namun pasal yang menjamin kemerdekaan pers ini tidak pernah dilaksanakan. Selain masalah penegakannya, ketentuan pasal 4 (3) UUPers ini pun belum jelas apakah tergolong delik aduan atau delik biasa. Kalau memang tergolong delik aduan, maka aparat penegak hukum tidak bisa disalahkan karena penyidik baru bisa bertindak apabila ada pihak yang mengadukan telah terjadi perbuatan yang berakibat terhambatnya pelaksanaan tugas - tugas wartawan. Sebaliknya apabila delik itu tergolong delik biasa, maka sekalipun tidak ada pengaduan, pihak aparat penegak hukum wajib memproses apabila diduga telah terjadi tindak pidana melanggar pasal 4 ayat (3) UUPers.

Keketentuan lain yang dapat dikatakan sebagai sekadar diatas kertas, adalah pasal 8 UUPers yang mengatakan, dalam melaksanakan profesinya wartawan mendapat perlindungan hukum. Selanjutnya dalam penjelasan pasal itu ditegaskan bahwa yang dimaksud dengan "perlindungan hkum" adalah jaminan perlindungan pemerintah dan atau masyrakat kepada wartawan dalam melaksanakan tugas, hak, kewajiban, dan peranannya sesuai dengan ketentuan peraturan perundang - undangan yang berlaku.

Mengapa ketentuan pasal ini dikatakan sebagai sekadar diatas kertas ?. tidak lain karena tidak diuraikan secara jelas dalam pasal itu apa sanksinya apabila jaminan perlindungan hukum oleh pemerintah dan atau masyarakat tersebut tidak dilaksanakan sebagaimana mestinya. Kemudian, kepada siapa atau kepada instansi mana wartawan mengadu apabila jaminan perlindungan hukum oleh pemerintah dan atau masyarakat tadi tidak dilaksanakan atau dilanggar. Halhal dimaksud serba tidak jelas, sehingga ketentuan pasal itu menjadi sekadar "pajangan" belaka. Padahal substansi yang terkandung dalam pasal 4 ayat (3) dan pasal 18 UUPers tersebut sangat penting artinya bagi terlaksananya tugastugas wartawan secara professional.

Kelemahan perangkat perundangundangan ini jugalah yang menjadi kendala ketika dilakukan advokasi kepada para wartawan. Bahkan terasa tidak adil karena kalau wartawan dinilai melanggar ketentuan UUPers dapat diproses dengan mudah. Tapi sebaliknya, jaminan perlindungan hukum yang diberikan UUPers terhadap wartawan tidak dapat 
dinikmati karena tidak jelas bagaimana pelaksanaannya. Ketentuan UUPers lain yang terkesan bersifat verbal belaka adalah perwujudan pasal 6 UUPers tentang peranan pers nasional. Dalam pasal itu ada lima peranan pers nasional yang sangat penting karena sekaligus dianggap sebagai perlindungan bagi pers dalam menjalankan profesinya.

Dalam penjelasan pasal 6 itu dikemukakan bahwa peranan pers tersebut akan mendorong ditegakkannya keadilan dan kebenaran serta diwujudkannya supremasi hukum untuk menuju masyrakat yang tertib. Makna penjelasan itu memang sangat ideal, namun sangat sulit melaksanakannya. Tidak lain karena UUPers tidak mengatur sanksi yang dapat dikenakan apabila peranan pers yang sangat penting tersebut dilanggar atau kalau ada pihakpihak yang menyebabkan pelaksanaan peranan pers tadi terhambat tidak terlaksana sebagaimana mestinya.

Tidak heran apabila ketentuan pasal 6 UUPers ini didalam praktek menimbulkan kontradiksi. Ambil contoh, tentang peranan pers "memenuhi hak masyarakat untuk mengetahui". Itu berarti semua informasi publik harus terbuka dan dibuka guna memenuhi hak masyarakat untuk mengetahui. Tapi disisi lain wartawaan sering menghadapi hambatan dalam melaksanakan peranannya memenuhi pasal 6 UUPers tersebut, dan terhadap yang menghambat dan menghalangi tadi tidak ada sanksi yang bisa dikenakan kepada mereka. Dengan demikian peranan pers yang dijamin dalam pasal itu menjadi tidak ada artinya.

Demikian juga mengenai peranan pers "melakukan pengawasan, kritik, koreksi dan saran terhadap hal- hal yang berkaitan dengan kepentingan umum". Dalam praktek, apabila ketentuan ini dilaksanakan secara konsekuen dan konsisten oleh wrtawan, justru bisa terjerat oleh pasal- pasal pidana yang dapat menyeret wartawan masuk penjara. Beberapa putusan pengadilan telah membuktikan hal itu. Maksud hati melakukan kontrol sosial secara professional sesuai amanat UUPers, tapi yang dihadapi adalah pasal- pasal pidana yang sangat mematikan.

Ketentuan lain yang sering menjadi kendala bagi pers adalah pasal 5 ayat (1) UUPers. Pasal itu mengatakan, pers nasional berkewajiban memberitakan peristiwa dan opini dengan menghormati norma- norma agama dan rasa kesusilaan masyarakat serta asas praduga tak bersalah. Hal ini menjadi kendala karena tidak jelas dan rinci disebut apa yang menjadi unsur atau kriteria dari "normanorma agama". "Rasa kesusilaan masyarakat" dan "Asas Praduga tak bersalah". Sebagai contoh tentang "Rasa kesusilaan masyarakat" (yang mana ?) sebab masyarakat kita sangat pluralis, sehingga sangat mungkin hal- hal atau kebiasaan yang dapat diterima disatu daerah, belum tentu bisa diterima masyarakat di daerah lain. Demikian sebaliknya, sehingga sangat subyektif dan relatif.

Demikian juga mengenai asas praduga tak bersalah, apa kriteria dan kapan asas ini diberlakukan. Sebab sampai sekarang masih diperdebatkan apakah asas ini diberlakukan sejak pemeriksaan pendahuluan. Termasuk tentunya oleh pers dalam pemberitaanya, karena ada juga pendapat yang mengatakan bahwa asas tersebut baru diberlakukan dalam proses pemeriksaan disidang pengadilan. Namun yang jelas ada perkembangan yang cukup signifikan berkaitan dengan pelaksanaan asas praduga tak bersalah ini. 
Tadinya pelaksanaan asas praduga tak bersalah ini diartikan sebagai adanya kewajiban wartawan untuk merahasiakan identitas seseorang yang berurusan dengan soal hukum. Oleh karena itulah selalu dilakukan pencantuman inisial seseorang atau penutupan mata dengan warna hitam pada gambar wajah tersangka atau terdakwa. Tidak lain maksudnya untuk merahasiakan identitas yang bersangkutan.

Tapi dalam perkembangannya perahasiaan identitas dengan cara seperti ini tidak lagi dilakukan secara ketat. Tidak lain karena ada pendapat yang mengatakan, perahasiaan identitas seseorang dengan mencantumkan inisial atau penutupan gambar wajah dengan warna hitam tidak ada kaitan dengan pelaksanaan asas praduga tak bersalah. Sebab yang menjadi hakikat asas praduga tak bersalah adalah, seseorang harus dianggap sebagai tidak bersalah sebelum ada putusan pengadilan yang telah mempunyai kekuatan hukum tetap. Itu berarti hak- hak seseorang sebagai subyek hukum harus tetap dihormati. Dalam kaitan dengan pemberitaan misalnya, hak jawab seseorang harus dipenuhi. Demikian juga dalam kegiatan jurnalistik mengenai diri seseorang yang berurusan dengan perkara jangan bersifat menghakimi, memojokkan, menyudutkan dan membuat kesimpulan kesalahan seseorang. Oleh karena itu pemberitaan atas diri seseorang yang berurusan dengan suatu perkara harus mengakomodir semua kepentingan termasuk pendapat dan pembelaan yang bersangkutan sedemikian rupa sehingga terpenuhi standar berita yang berimbang (cover both side) dan adil.

Lagi pula, rumusan pasal 5 ayat (1) UUPers yang terlalu umum karena tidak limitatif dan tidak jelas kriteria apa yang dimaksud dengan "norma - norma agama", "rasa kesusilaan masyarakat", dan "asas praduga tak bersalah", menjadi tergolong "pasal- pasal karet. Dikatakan demikian karana dengan rumusan bersifat umum itu memberi keleluasaan bagi penguasa untuk menafsirkan dan menerapkannya sesuai keinginannya. Peraktek penguasa seperti inilah yang dialami oleh pers ketika dihadapkan kepada haatzaai artikelen (pasal- pasal menyebarluaskan perasaan kebencian dan permusuhan dalam masyarakat terhadap pemerintah yang sah).

Ketentuan pasal 5 ayat (1) UUPers inipun menjadi sangat berat bagi pers karena menurut pasal 18 ayat (2), perusahaan pers yang melanggaran ketentuan itu dapat dikenakan pidana denda maksimal Rp. 500 juta. Dikatakan berat karena seperti dikemukakan, rumusan pasal itu sangat umum sehingga memberi peluang bagi penguasa untuk menafsirkannya. Hal lain yang juga perlu mendapat berkenaan dengan advokasi wartawan ini adalah, pelaksanaan penegakan ketentuan UUPers itu sendiri. Sebagai contoh mengenai ketentuan persyaratan perusahaan pers. Memang UUPers tidak lagi mengenal izin seperti UUPers yang berlaku sebelumnya. Tapi dalam UUPers yang berlaku sekarang ada beberapa ketentuan persyaratan yang harus dipenuhi perusahaan pers. Antara lain, perusahaan pers berbentuk badan hukum Indonesia, mengumumkan nama, alamat, dan penanggung jawab serta nama dan alamat percetaka. Mengenai syarat badan hukum ini ada pemahaman yang kurang pas oleh sementara kalangan. Seolaholah, dengan terbentuknya sebuah badan hukum seperti PT (Perseroan Terbatas) dengan akte Notaris, telah dengan sendirinya memperoleh status hukum. Padahal untuk memperoleh status badan hukum. Padahal untuk memperoleh status 
badan hukum itu harus diproses ke Departemen hukum dan HAM.

Yang menjadi pertanayaan sekrang, apakah semua penerbitan yang begitu banyak beredar di masyarakat sekarang ini telah memenuhi syarat badan hukum dimaksud. Untuk itu perlu dilakukan penelitian dan penyidikan dilapangan. Tapi persoalannya, instansi mana yang melakukan. Ada anggapan, hal itu menjadi tugas Dewan Pers. Anggapan tersebut tidak benar karena Dewan Pers bukan aparat penyidik di samping tidak diberi wewenang oleh Pers, juga tidak punya aparat untuk melakukan pemeriksaan.

Sadar akan berbagai permasalahan yang dihadapi pers seperti dikemukakan di atas disatu sisi dan masalah penegakan hukum disisi laian, maka sejak Oktober 2001 sudah diupayakan Memorandum of Understanding (MOU) antara Kpolri dan Dewan Pers. Menyangkut materi yang termaktup dalam Naskah Kesepahaman itu telah dilakukan beberapa kali pembahasan antara Mabes Polri dan Dewan Pers. Namun MoU yang sangat penting artinya bagi perlindungan pers itu, belum menjadi kenyataan. Konsep naskah Kesepahaman itu terdiri dari dua bagian, naskah yang satu berisikan ketentuan mengenai Perlindungan bagi kemerdekaan Pers, dan yang satu lagi mengenai Perlindungan bagi Wartawan.

Dalam naskah Perlindungan bagi Kemerdekaan Pers, ada pembagian tugas antara kepolisian dan Dewan Pers. Mengenai masalah penegakan hukum sepenuhnya menjadi tanggung jawab pihak Kepolisian, sedangkan mengenai penegakan etika pers menjadi tanggung jawab Dewan Pers. Salah satu penegakan hukum itu adalah merupakan tugas dan tanggung jawab pihak kepolisian untuk melakukan penyelidikan dan penyidikan mengenai keberadaan badan hukum perusahaan pers apakah sudah memenuhi syarat sesuai ketentuan UUPers apa tidak.

Misalnya mengenai badan hukum, apakah sudah memperoleh status badan hukum apa tidak, dan apabila terdapat perusahaan pers yang belum memenuhi syarat badan hukum, dapat dikenakan pidana denda maksimal Rp. 100 juta sesuai ketentuan pasal 18 ayat UUPers.

Penertiban mengenai persyaratan badan hukum ini perlu dilakukan lebih- lebih karena perusahaan perbitan tidak memerlukan izin. Sebab kalau tidak ditertibkan bisa merusak citra pers yang benar- benar mentaati peraturan. Adalah menjadi pengalaman Dewan Pers ketika mengirimkan surat kepada beberapa perusahaan penerbitan, tapi kemudian dikembalikan dengan catatan "tidak dikenal". Bagi masyarakat luas, semua penerbitan yang beredar itu dianggap sebagai pers pers nasional, padahal belum tentu demikian. Sebab perusahaan tersebut belum tergolong pers karena belum memenuhi syarat sesuai ketentuan UUPers.

Lebih lanjut mengenai naskah kesepahaman tentang Perlindungan Bagi Wartawan ketika terjadi aksi demonstrasi, konflik dan kerusuhan masal, memuat beberapa ketentuan antara lain sebagai berikut :

1. Wartawan bukanlah partisipan aksi, sehingga polisi tidak seharusnya memperlakukan wartawan sebagai peserta aksi;

2. Wartawan selalu menggantungkan kartu Pers (atau kartu pengenal lain) dibadannya sebagai identifikasi; 
3. Polisi wajib memberi peringatan sebelumnya ketika tindakan pemaksaan (terhadap demonstran) akan dilakukan, antara lain dengan meminta para wartawan untuk memisahkan diri dari pengunjuk rasa;

4. Pada saat situasi kacau akibat pembubaran paksa aksi unjuk rasa itu, polisi harus menghentikan tindakan pemaksaan (pemukulan atau pengusiran) jika seseorang menunjukkan identitas wartawan;

5. Tindakan mengejar, memukul, dan merampas alat kerja wartawan tidak dapat dibenarkan.

\section{Kesimpulan}

Kita tiba pada kesimpulan, selain aksi kekerasan secara fisik seperti dikemukakan dibagian terdahulu, maka yang tidak kurang pentingnya adalah kekawatiran atas aksi kekerasan secara non fisik, yaitu diterapkannya pasal- pasal pidana tergolong usang secara kaku, demikian juga perangkat perundang- undangan tergolong mendistorsi kemerdekaan pers, disamping tidak dilaksanakannya ketentuan hukum positif yang bertujuan menjaga dan mempertahankan kemerdekaan pers. Sebab itu diskusi yang intensif antara pers dengan jajaran aparat penegak hukum sangat penting, sehingga satu dengan yang lain menghormati pelaksanaan fungsi masing- masing. Khusus dengan aparat kepolisian, MoU yang telah ditawarkan Dewan Pers dan sudah sempat mendapat pembahasan, perlu segera diwujudkan dalam upaya menghindari pers dari hambatan dan gangguan dalam menjalankan fungsi, hak, kewajiban dan peranan pers sesuai UUPers.
Disamping berbagai kendala yang dihadapi pers dalam menjalankan fungsi, hak dan peranannya menurut UUPers seperti digambarkan diatas, kendala lain yang sangat penting dan strategis ialah, tidak adanya satu instrumen yang dapat berfungsi efektif sehingga penegakan HAM melalui media massa dapat dilaksanakan seooptimal mungkin. Secara khusus disorot ketentuan pasal 4 ayat (1) UUPers. Pasal itu mengatakan, kemerdekaan pers dijamin sebagai hak asasi warga negara. Kemudian dalam penjelasan ditegaskan, yang dimaksud dengan kemerdekaan pers dijamin sebagai hak asasi warga negara adalah bahwa pers bebas daari tindakan pencegahan, pelarangan dan atau penekanan agar hak masyarakat untuk memperoleh informasi terjamin.

Rumusan pasal 8 dan penjelasan itu memang ideal, tapi menjadi tanpa makna untuk kalau kemerdekaan pers yang dijamin sebagai hak warga negara tidak diikuti oleh sanksi yang tegas dalam hal terjadi pelanggaran atas prinsip tersebut. Padahal prinsip kemerdekaan pers yang dijamin sebagai hak warga negara sangat penting artinya bagi peranan pers dalam penegakan HAM.

Dengan demikian jelaslah, bahwa disatu sisi konstitusi dan UUUPers sudah sangat menjamin peranan pers dalam menegakkan HAM, tapi disisi lain masih terdapat jumlah pasal dan perangkat perundang - undangan yang dapat mendistorsi peranan pers tersebut. Peranan pers dalam menegakkan HAM inipun bisa tidak efektif apabila insane pers tidak melaksanakan tugas- tugas jurnalistiknya sesuai norma etik dan norma hukum. Dikatakan demikian karena etik itulah sebagai rambu- rambu, kaidah penuntun sekaligus pemberi arah kepada para wartawan tentang apa yang seharusnya 
dilakukan dan tentang apa yang seharusnya tidak dilakukan dalam menjalankan tugas- tugas jurnalistiknya. Demikian juga dengan norma hukum.

Jadi, peranan pers dalam menegakkan HAM menjadi tidak efektif apabila wartawan tidak mentaati norma etik dan norma hukum. Bahkan permberitaan pers akan HAM menjadi kontra produktif terhadap upaya penegakan HAM itu sendiri atau bersifat anarkis apabila tidak mentaati norma etik dan norma hukum.

\section{DAFTAR PUSTAKA}

1. Undang - Undang Dasar Negara Kesatuan RI. 1945

2. Kitab Undang-undang Hukum Pidana / KUHP

3. Undang-undang No 40 tahun 1999 Tentang Pers

4. Undang-undang No 39 tanun 1999 tentang Hak Asasi Manusia 